Abstract 514 Table 1 Demographic and pathologic characteristics of women with endometrial cancer by menopausal status

\begin{tabular}{|c|c|c|c|c|}
\hline Factor & $\begin{array}{c}\text { Total } \\
(\mathrm{n}=244)\end{array}$ & $\begin{array}{c}\text { Premenopausal } \\
(\mathrm{n}=45)\end{array}$ & $\begin{array}{c}\text { Postmenopausal } \\
(n=199)\end{array}$ & $P$ value \\
\hline Age (mean, SD) & $64.3(11.9)$ & $43.1(19.9)$ & $68.2(14.4)$ & 0.032 \\
\hline $\mathrm{BMI} \mathrm{Kg} / \mathrm{m}^{2}($ mean, SD) & $29.7(7.7)$ & $28.7(11.2)$ & $30.6(10.3)$ & 0.6 \\
\hline Parity (mean, SD) & $2.0(1.37)$ & $1.1(0.8)$ & $2.15(1.3)$ & 0.04 \\
\hline Tobacco use (n, \%) & $36(17.4)$ & $11(28.9)$ & $25(14.9)$ & 0.039 \\
\hline Diabetes mellitus (n, \%) & $39(16.3)$ & $4(8.9)$ & $35(18.0)$ & 0.5 \\
\hline Hypertension (n, \%) & $123(50.6)$ & $6(13.0)$ & $117(59.4)$ & 0.001 \\
\hline Lynch syndrome (n, \%) & $0(0.0)$ & - & - & - \\
\hline $\begin{array}{l}\text { Surgical treatment }(\mathrm{n}, \%) \\
\text { Hysterectomy } \\
\text { Bilateral salpingooophorectomy } \\
\text { Pelvic lymphadenectomy } \\
\text { Para-aortic lymphadenectomy }\end{array}$ & $\begin{array}{l}244(100) \\
244(100) \\
239(98.0) \\
94(38.2)) \\
67(28.3)\end{array}$ & $\begin{array}{c}- \\
- \\
44(97.8) \\
18(39.1) \\
17(37.0)\end{array}$ & $\begin{array}{c}- \\
- \\
195(98.0) \\
76(38.0) \\
60(30.0)\end{array}$ & $\begin{array}{l}- \\
- \\
0.9 \\
0.4 \\
0.19\end{array}$ \\
\hline $\begin{array}{l}\text { Histology }(\mathrm{n}, \%) \\
\text { Endometrioid } \\
\text { Non endometrioid }\end{array}$ & $\begin{array}{c}212(86.2) \\
34(13.8)\end{array}$ & $\begin{array}{c}45(97.8) \\
1(2.2)\end{array}$ & $\begin{array}{c}167(83.5) \\
33(16.5)\end{array}$ & 0.01 \\
\hline $\begin{array}{l}\text { Grade }(\mathrm{n}, \%) \\
1-2 \\
3 \\
\end{array}$ & $\begin{array}{c}176(71.8) \\
58(23.7)\end{array}$ & $\begin{array}{c}36(79.5) \\
6(13.0) \\
\end{array}$ & $\begin{array}{c}140(70.6) \\
52(26.1)\end{array}$ & 0.06 \\
\hline $\begin{array}{l}\text { Myometrial invasion (n, \%) } \\
\quad<50 \% \\
\quad \geq 50 \%\end{array}$ & $\begin{array}{c}168(69.1) \\
75(30.9)\end{array}$ & $\begin{array}{l}36(80.0) \\
9(20.0)\end{array}$ & $\begin{array}{c}132(66.7) \\
66(33.3)\end{array}$ & 0.08 \\
\hline Lymphovascular space invasion $(\mathrm{n}, \%)$ & $45(18.5)$ & $8(17.4)$ & $37(18.8)$ & 0.39 \\
\hline $\begin{array}{l}\text { Stage (n, \%) } \\
\text { I-II } \\
\text { III-IV }\end{array}$ & $\begin{array}{l}214(87.4) \\
31(12.6)\end{array}$ & $\begin{array}{l}36(80.4) \\
9(19.6)\end{array}$ & $\begin{array}{l}177(88.9) \\
22(11.1)\end{array}$ & 0.118 \\
\hline $\begin{array}{l}\text { Adjuvant treatment (n, \%) } \\
\text { Chemotherapy } \\
\text { Radiotherapy }\end{array}$ & $\begin{array}{l}34(14.2) \\
88(36.2)\end{array}$ & $\begin{array}{c}7(15.6) \\
13(28.9)\end{array}$ & $\begin{array}{l}27(13.8) \\
75(37.9)\end{array}$ & $\begin{array}{l}0.757 \\
0.257\end{array}$ \\
\hline
\end{tabular}

\section{RETROSPECTIVE ANALYSIS OF OVERALL SURVIVAL AND PATTERN OF RELAPSE UTILISING SEQUENTIAL CHEMORADIOTHERAPY IN HIGH-RISK ENDOMETRIAL CANCER}

${ }^{1} \mathrm{~S}$ Anderson*, ${ }^{1} \mathrm{~K}$ Baillie, ${ }^{1} \mathrm{~A}$ Sadozye, ${ }^{1} \mathrm{~N}$ Reed, ${ }^{1} \mathrm{R}$ Harrand, ${ }^{1} \mathrm{C}$ Crearie, ${ }^{2} \mathrm{~T}$ Mueller,

${ }^{2 ; 3} \mathrm{M}$ Bennie, ${ }^{1} \mathrm{~K}$ Graham. 'Beatson West of Scotland Cancer Centre, NHS Greater Glasgow and Clyde; ; ${ }^{2}$ Strathclyde Institute of Pharmacy and Biomedical Sciences, University of Strathclyde; ; ${ }^{3}$ Public Health and Intelligence Strategic Business Unit, NHS National Services UK

\subsection{6/ijgc-2021-ESG0.163}

Introduction/Background* Management of endometrial cancer (EC) consists of surgery, followed by tailored adjuvant therapy in intermediate to high-risk disease. PORTEC3 reported 5-year overall survival (OS) of $81 \%$ and $25 \%$ relapse rate (pelvic failure $6 \%$ and distant failure $24 \%$ ) in women who received concurrent chemoradiotherapy followed by 4 cycles of chemotherapy, with most marked benefit demonstrated in stage III and/or high grade serous (HGS) EC. In the West of Scotland Cancer Network (WoSCAN), standard post-operative protocol for high-risk disease is 4-6 cycles of carboplatin/paclitaxel prior to external beam radiotherapy (EBRT), 4500cGy/ 25 fractions. We compared our practice to PORTEC3 to investigate if alternative sequencing affects OS and/or pattern of relapse.
Methodology Data were collected retrospectively from electronic clinical records in WoSCAN patients who commenced adjuvant chemotherapy between January 2012 and December 2016. Statistical analysis was performed using $\mathrm{R}^{\circledR}$. OS was estimated using Kaplan-Meier method.

Result(s)* 108 patients were identified, 57 had chemotherapy $+/$ - vaginal brachytherapy and 51 had chemotherapy + EBRT. In the EBRT cohort, median age was 62 years (range 47-78), and FIGO stage was as follows: IB (13\%); II (18\%); III (59\%); IVB (10\%). LVSI was positive in $69 \%$ and nodal staging performed in 39\%. Pathology consisted of: EEC (61\%), HGS (22\%), carcinosarcoma (10\%), or other $(7 \%)$. Residual disease and/or positive margins were present in over $10 \%$. Median number of chemotherapy cycles was 4 (range $3-6$ ), and $37 \%$ had 5 or 6 cycles. 95\% completed EBRT. OS at 3 -years was $72 \%$ (95\% Confidence Interval 61-86). Relapse rate was 39\% (pelvic failure $17 \%$ and distant failure $33 \%)$.

Conclusion* Pelvic and distant failure rates were higher and OS was less favourable in our series, but over $30 \%$ of patients would have been excluded from the PORTEC 3 trial based on pathology, stage, and residual disease. Chemotherapy prior to EBRT does not appear to result in better outcomes, but this cohort consisted of women with very highrisk EC. 